\title{
Ichthyofauna of the upper Juruena river on Chapada dos Parecis, Mato Grosso, Brazil
}

\author{
Willian Massaharu Ohara* \& Marina Vianna Loeb \\ Museu de Zoologia da Universidade de São Paulo, São Paulo, SP, Brazil \\ *Corresponding author: Willian Massaharu Ohara, e-mail: willianmohara@gmail.com
}

OHARA, W.M., LOEB, M.V. Ichthyofauna of the upper Juruena river on Chapada dos Parecis, Mato Grosso, Brazil. Biota Neotropica. 16(4): e20160224. http://dx.doi.org/10.1590/1676-0611-BN-2016-0224

\begin{abstract}
The fishes herein included were collected in four small streams of the upper rio Tapajós basin. Through fieldwork carried out in 2011, 2013 and 2014 during the low water season 1.728 specimens belonging to 22 species distributed in 11 families, and five orders were captured. Characidae was the most representative family both in number of species and specimens captured. The most abundant species were Hyphessobrycon melanostichos, H. hexastichos, and H. notidanos. Five species are recognized as new, and four as endemic to the upper rio Tapajós basin. This study represents the first fish inventory for the region and will provide valuable information for the conservation of the poorly known diversity of fishes of the Chapada dos Parecis, in the headwaters of the upper rio Tapajós basin.
\end{abstract}

Keywords: South America, Neotropical fish, Amazon, endemism.

\section{Ictiofauna do alto rio Juruena na Chapada dos Parecis, Mato Grosso, Brasil}

\begin{abstract}
Resumo: Os peixes registrados aqui foram coletados em quatro igarapés da bacia do alto rio Tapajós. Expedições realizadas em 2011, 2013 e 2014 durante a estação de seca resultaram na coleta de 1.728 indivíduos pertencendo à 22 espécies distribuídas em 11 famílias e cinco ordens. Characidae foi a família com o maior número de espécies e espécimes capturados. As espécies com maior abundância foram Hyphessobrycon melanostichos, H. hexastichos e H. notidanos. Cinco espécies são reconhecidas como novas e quatro como endêmicas da bacia do alto rio Tapajós. Este trabalho representa o primeiro inventário sobre os peixes da região e fornecerá informações valiosas para a conservação da diversidade pouco conhecida de peixes da Chapada dos Parecis, nas cabeceiras da bacia do alto rio Tapajós.
\end{abstract}

Palavras-chave: América do Sul, peixe Neotropical, Amazônia, endemismo.

\section{Introduction}

The Neotropical region, that includes the South and part of Central America, harbours the most diverse freshwater fish fauna in the world including 5.400 registered species (Reis 2013), with estimates of a final number between $8.000-9.000$ species (Schaefer 1998, Reis et al. 2016). Most of this ichthyofaunal diversity is located in the Amazon basin (Amazon, Orinoco and Guiana basins), in which 2.354 (Albert et al. 2011) or 2.411 (Reis et al. 2016) valid fish species are included. Most of the major tributaries of the Amazon river basin, still lack an inventory of their fish species, including the rio Tapajós.

Located in the Brazilian Shield the $1.784 \mathrm{~km}$ long, rio Tapajós is one of the largest tributaries of rio Amazonas (Costa 2007). Its upper portion was until recently virtually unknown by ichthyologist (Britski \& Lima 2008). However, on the last decades, the collecting activity largely increased in the area, 97 of the 109 species presently known from the rio Tapajós basin having been described in the past 30 years. Currently, approximately 300 fishes are registered from the rio Tapajós basin (Ferreira et al. 1998, Camargo et al. 2005, Silva-Oliveira et al. 2016), but collecting efforts have mostly concentrated on the lower and middle portions of the basin, so that a catalogue of fishes of the upper rio Tapajós basin is still lacking. This contribution represents the first attempt to survey the fish species of the upper rio Tapajós basin and will certainly provide valuable information for future studies especially on conservation of the poorly known diversity of fishes of the rio Tapajós basin.

\section{Material and Methods}

Study Area

The rio Tapajós is formed by the confluence of the Teles Pires and Juruena rivers. The rio Juruena is about $1.240 \mathrm{Km}$ long and is formed by several tributaries draining from the Chapada dos Parecis, an important watershed between three river systems (Madeira, Paraguai and Tapajós river basins) with moderate altitude $(750 \mathrm{~m})$, located at the western border of the Brazilian Shield. The rivers in Chapada dos Parecis, tributaries of the rio Juruena (i.e. Mutum, 12 de Outubro, Primavera, Camararezinho, Sacre, Formiga, Juína, Sangue), where samples were obtained for this study, are generally rectilinear, embedded and deep, characterized by turbulent waters and presence of many waterfalls. The studied area is about 500 to 510 meters a.s.1., and is located between Comodoro and Vilhena towns, near BR 364 (Figure 1) on the Chapada dos Parecis and are considered headwater streams entering the upper rio Juruena, rio Tapajós basin. 


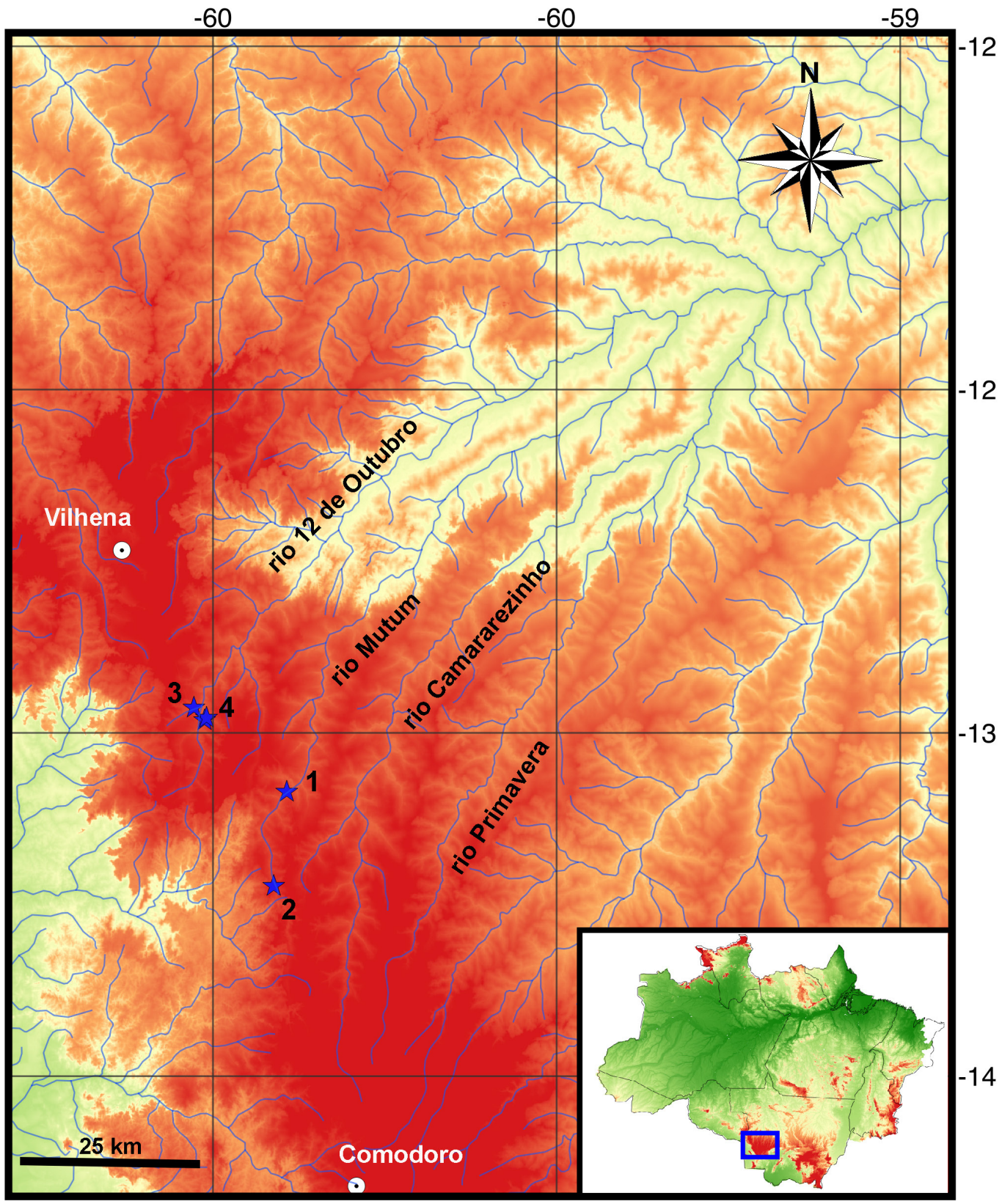

Figure 1. Map of the study area showing the four stations sampled (indicated by number) from the upper rio Juruena, rio Tapajós basin, Mato Grosso, Brazil.

Station $1\left(13^{\circ} 05^{\prime} 08^{\prime} \mathrm{S}, 59^{\circ} 53^{\prime} 32^{\prime \prime} \mathrm{W}\right)$ - igarapé Mutum located near BR 364, 3-6 $\mathrm{m}$ wide and 0.5-2.5 $\mathrm{m}$ deep, preserved riparian vegetation, swift current, and sand, pebbles and dead leaves on the bottom (Fig. 2a).

Station 2 (1313'23'S, 5954'42”W) - Headwater of igarapé Mutum in flooded portions of the stream due to damming caused by road, $6-8 \mathrm{~m}$ wide and 0.5-1.5 m deep, lentic environment, mud and decomposed organic matter on the bottom.

Station $3\left(12^{\circ} 58^{\prime} 41^{\prime}\right.$ 'S, $60^{\circ} 00^{\prime} 34^{\prime}$ 'W) - igarapé 12 de Outubro located near BR 364, 2-4 m wide and 0.5-2 $\mathrm{m}$ deep, few preserved riparian vegetation, swift current, and sand and dead leaves on the bottom (Fig. 2b).

Station $4\left(12^{\circ} 57^{\prime} 50^{\prime} \mathrm{S}, 60^{\circ} 01^{\prime} 40^{\prime \prime} \mathrm{W}\right)$ - Tributary of 12 de Outubro located near BR 364, 1-2 $\mathrm{m}$ wide and 0.5-1.7 m deep, preserved riparian vegetation, swift current, subaquatic vegetation and sand on the bottom (Fig. 2c).

\section{Sampling}

Samples were taken in November 2011, July and August 2013, September and November 2014 in four stations. Sampling took one hour long, and four were undertaken during the day and one during the nocturnal period. The following gears were used: trapezoid hand-nets with area of $1 \mathrm{~m}^{2}$ and internode distance of $0.1 \mathrm{~cm}$, seine-nets $3-5 \mathrm{~m}$ wide, $1.5-2.5 \mathrm{~m}$ deep and internode distance of $1 \mathrm{~cm}$ and casting-nets $2.5 \mathrm{~m}$ deep, $22 \mathrm{~m}$ of circumference and internode distance of $1.5 \mathrm{~cm}$. Photographs were taken in three stations that were was georeferenced with a GPS device. Abiotic data such as depth, water transparency and soil were observed in situ. No sazonal differences were detected in the abiotic data. Collection permit was granted by Instituto Brasileiro do Meio Ambiente e dos Recursos Naturais Renováveis (registration number IBAMA 83/2012, May 2012-September 2013). 


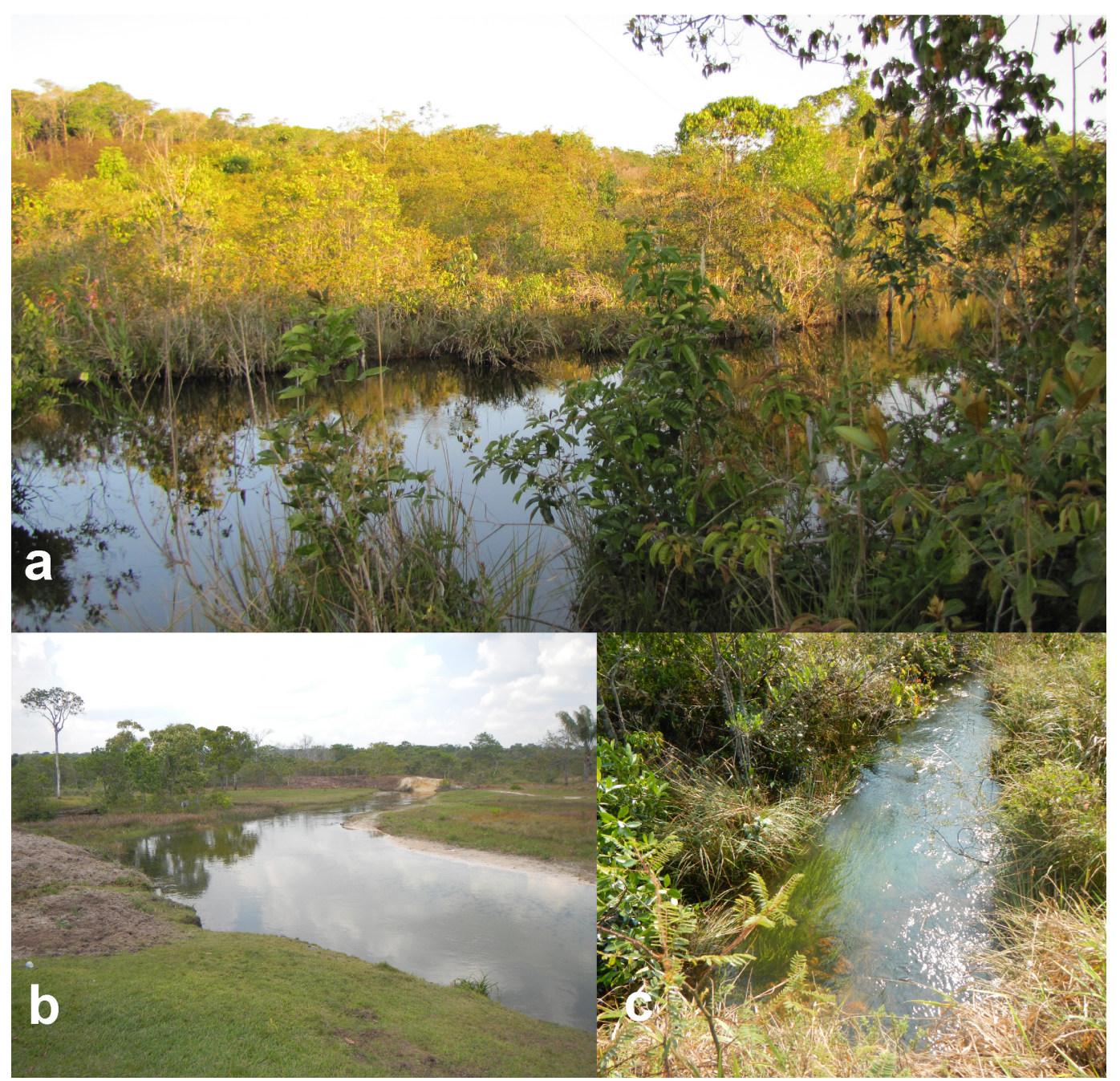

Figure 2. Habitats of three stations sampled from the upper rio Juruena, rio Tapajós basin, Mato Grosso, Brazil. (a) igarapé Mutum; (b) headwaters of igarapé Mutum; (c) igarapé 12 de Outubro; (d) tributary of 12 de Outubro.

The sampled fishes were anesthetized with clove-oil (1ml/liter), put in plastic bags, fixed in $10 \%$ formalin for 48 hours and transferred to $70 \%$ ethanol. The material was then counted and identified to the lowest possible level using revisionary studies by Bertaco \& Malabarba (2007), Bertaco \& Carvalho (2005 a, b), Carvalho \& Bertaco (2006), Costa (2001), Queiroz et al. (2013), Reis et al. (2005), and comparisons with identified material deposited in the fish collections whenever needed. The classification adopted follows Reis et al. (2003), Wiley \& Jonson (2010), and Van Der Laan et al. (2014), with genera listed in alphabetical order within each family. Voucher specimens were deposited in the fish collections of the Museu de Zoologia da Universidade de São Paulo (MZUSP) and the Universidade Federal de Rondônia, Ictiologia (UFRO-I). Species and specimens were counted for each registered species with data organized in Table 1 and Figures 3 and 4.

\section{Results}

The species recorded from the upper rio Tapajós basin are listed in Table 1 and the corresponding photos are provided in Figures 3 and 4. A total of 1.728 specimens representing 22 species distributed in 11 families, and five orders were collected in four stations in both the igarapé Mutum and the igarape 12 de Outubro. Characiformes (55\%, 12 species) was the predominant group, followed by Siluriformes ( $28 \%, 6$ species), Gymnotiformes ( $9 \%, 2$ species), Labriformes (4\%, 1 species) and Cyprinidontiformes (4\%, 1 species) in number of recorded species (Figure 5).

The most representative families considering number of species collected were Characidae (seven species), and Heptapteridae (five species). In terms of captured specimens Characiformes prevailed again $(1.498$ specimens collected $=86 \%)$, followed by Siluriformes ( 129 specimens collected $=7 \%$ ), Gymnotiformes and Labriformes (49 specimens each $=3 \%$ ) and Cyprinodontiformes ( 3 specimens $=1 \%$ ) (Figure 6). Characidae includes the three most abundant species recorded from the upper rio Tapajós basin: Hyphessobrycon melanostichos Carvalho \& Bertaco, 2005, Hyphessobrycon hexastichos Bertaco \& Carvalho, 2005, and Hasemania nambiquara Bertaco \& Malabarba, 2007, with 610, 305 and 205 captured specimens respectively, representing $65 \%$ of the total captured specimens. On the other hand one single specimen of Hoplerythrinus unitaeniatus and Pimelodella sp. were recorded. Moenkhausia sp. and Melanorivulus modestus (Costa, 2001) also presented low abundance, with two and three captured specimens, respectively.

A total of 1.104 specimens belonging to 20 species were recorded from the igarapé Mutum (Stations 1 and 2). The fish fauna is composed by Characiformes (12 species, 913 specimens), Siluriformes (6 species, 


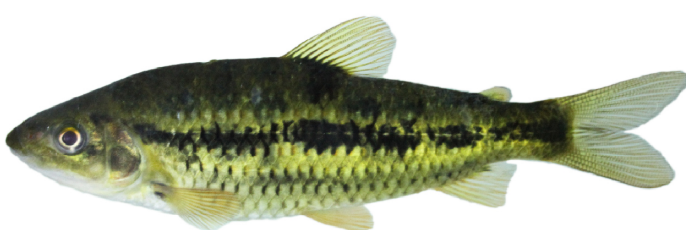

Leporinus aff. granti

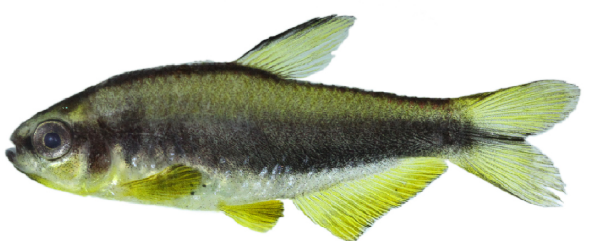

Hasemannia nambiquara

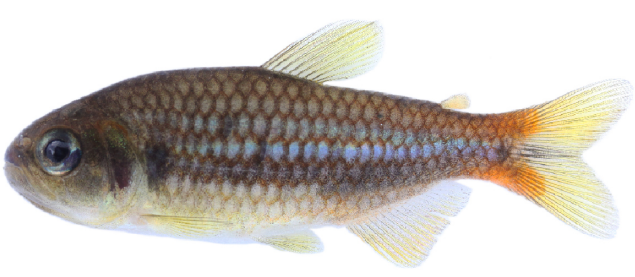

Hemigrammus skolioplatus

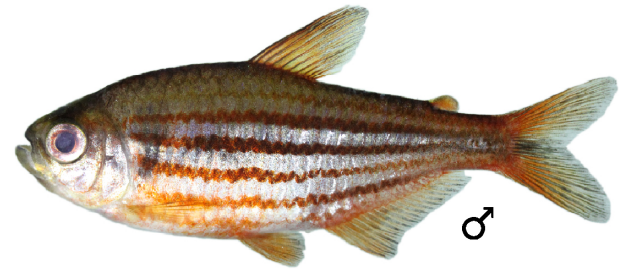

Hyphessobrycon hexastichos

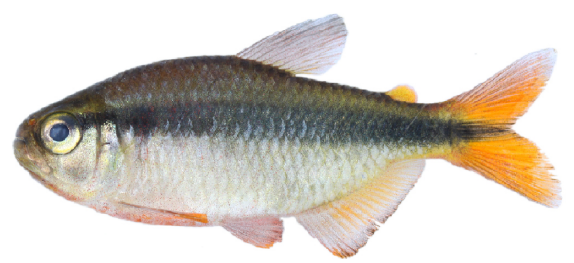

Hyphessobrycon melanostichos

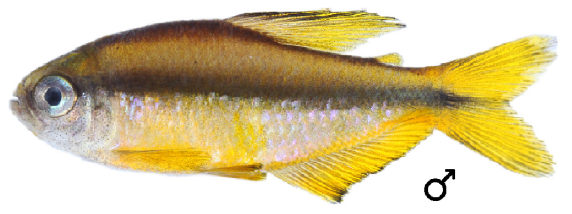

Hyphessobrycon notidanos

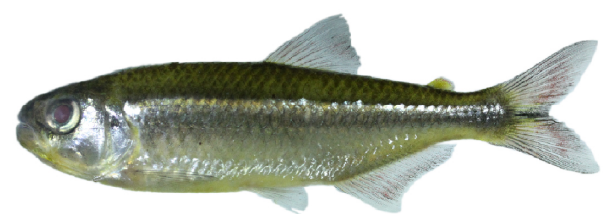

Knodus sp.

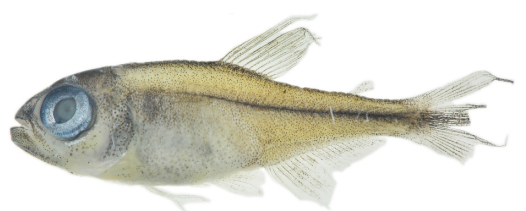

Moenkhausia sp.

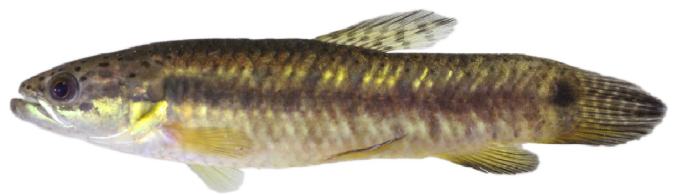

Erythrinus erythrinus

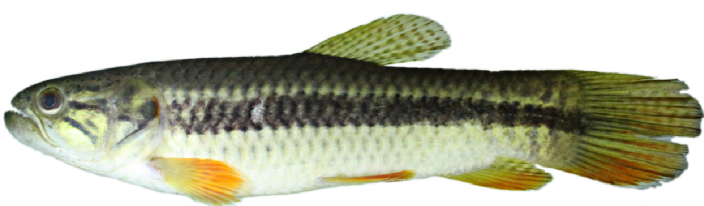

Hoplerythrinus unitaeniatus

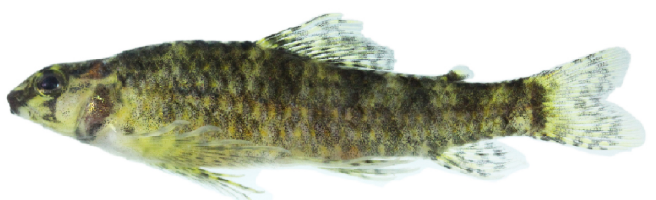

Melanocharacidium cf. dispilomma

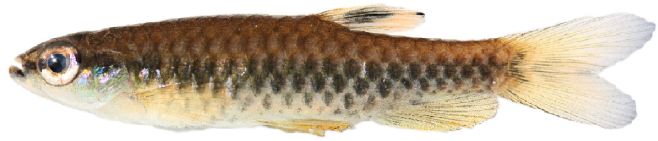

Pyrrhulina aff. marilynae

Figure 3. Characiformes registered from the upper rio Juruena, rio Tapajós basin, Mato Grosso, Brazil.

118 specimens), Gymnotiformes (1 species, 40 specimens) and Labriformes (1 species, 33 specimens). No Cyprinodontiformes species was captured in the igarapé Mutum. The most representative families in number of species and specimens were Characidae (seven species), and Heptapteridae (five species). Characidae includes the three most abundant species registered in the igarapé Mutum, Hyphessobrycon hexastichos, Hasemania nambiquara, and Hyphessobrycon melanostichos, with 358, 205 and 189 captured specimens respectively.
Twenty species $(90 \%)$ with 1.068 captured specimens $(62 \%)$ were registered in the Station 1. A low number of species and specimens were registered in all the other three stations. The Station 2, the headwater of igarapé Mutum, was represented by eight species (38\%) and 36 captured specimens $(2 \%)$, the lowest values of captured species and specimens herein recorded. Stations 3 and 4 are located in the igarapé 12 de Outubro basin. A total of 624 specimens belonging to 11 species were collected. The fish fauna is composed by Characiformes ( 6 species, 585 specimens), Siluriformes 
Table 1. List of species registered in four stations from the upper rio Juruena, rio Tapajós basin, Mato Grosso, Brazil.

\begin{tabular}{|c|c|c|c|c|c|c|c|c|}
\hline \multirow{2}{*}{ Ordem } & \multirow{2}{*}{ Family } & \multirow{2}{*}{ Species } & \multicolumn{4}{|c|}{ Sampling Stations } & \multirow{2}{*}{$\mathbf{N}$} & \multirow{2}{*}{ Vouchers } \\
\hline & & & 1 & 2 & 3 & 4 & & \\
\hline \multirow[t]{13}{*}{ Characiformes } & Characidae & Hasemania nambiquara & 198 & 7 & 0 & 0 & 205 & UFRO-I 12346, 12392, 22736 \\
\hline & & Hemigrammus skolioplatus & 1 & 0 & 0 & 11 & 12 & MZUSP 115497 \\
\hline & & Hyphessobrycon hexastichos & 356 & 2 & 0 & 0 & 358 & UFRO-I 12297, 12318, 12681 \\
\hline & & Hyphessobrycon melanostichos & 180 & 9 & 404 & 17 & 610 & UFRO-I 12281, 12657, 22884 \\
\hline & & Hyphessobrycon notidianos & 5 & 0 & 2 & 97 & 104 & MZUSP 115505, 115501 \\
\hline & & Knodus sp. & 11 & 9 & 9 & 1 & 30 & UFRO-I 12305, 22844, 22905 \\
\hline & & Moenkhausia sp. & 2 & 0 & 0 & 0 & 2 & UFRO-I 22881 \\
\hline & Erythrinidae & Erythrinus erythrinus & 1 & 1 & 1 & 4 & 7 & UFRO-I 22738, 22846 \\
\hline & & Hoplerythrinus unitaeniatus & 1 & 0 & 0 & 0 & 1 & UFRO-I 22846 \\
\hline & Anostomidae & Leporinus aff. granti & 11 & 0 & 0 & 0 & 11 & UFRO-I 12300, 22717 \\
\hline & Crenuchidae & Melanocharacidium cf. dispilomma & 113 & 0 & 0 & 0 & 113 & UFRO-I 12656, 22734, \\
\hline & Lebiasinidae & Pyrrhulina aff. marilynae & 1 & 5 & 37 & 2 & 45 & UFRO-I 22718 \\
\hline & Callichthyidae & Megalechis thoracata & 11 & 2 & 3 & 2 & 18 & UFRO-I 12684, 22732, 22847 \\
\hline \multirow{5}{*}{ Siluriformes } & Heptapteridae & Cetopsorhamdia sp.1 & 81 & 0 & 0 & 0 & 81 & UFRO-I 12343, 12682, 22733 \\
\hline & & Cetopsorhamdia sp.2 & 11 & 0 & 0 & 0 & 11 & UFRO-I 22716 \\
\hline & & Cetopsorhamdia sp.3 & 4 & 0 & 0 & 6 & 10 & MZUSP 115498, 115478 \\
\hline & & Pimelodella sp. & 1 & 0 & 0 & 0 & 1 & UFRO-I 22885 \\
\hline & & Phenacorhamdia sp. & 8 & 0 & 0 & 0 & 8 & UFRO-I 22887 \\
\hline Labriformes & Cichlidae & Aequidens cf. rondoni & 32 & 1 & 4 & 12 & 49 & UFRO-I 12277, 12673, 22843 \\
\hline \multirow[t]{2}{*}{ Gymnotiformes } & Hypopomidae & Brachyhypopomus sp.n. & 0 & 0 & 0 & 9 & 9 & MZUSP 115496 \\
\hline & Sternopygidae & Eigenmannia sp.n. & 40 & 0 & 0 & 0 & 40 & UFRO-I 12275, 12683, 22737 \\
\hline Cyprinodontiformes & Cynolebiidae & Melanorivulus modestus & 0 & 0 & 3 & 0 & 3 & MZUSP 115507 \\
\hline \multicolumn{3}{|c|}{ Total number of specimens } & 1068 & 36 & 463 & 161 & 1728 & \\
\hline \multicolumn{3}{|c|}{ Total number of species } & 20 & 8 & 8 & 10 & 22 & \\
\hline
\end{tabular}

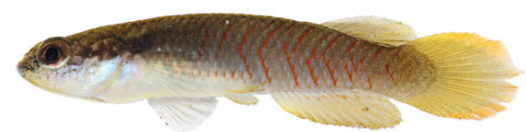

Melanorivulus modestus
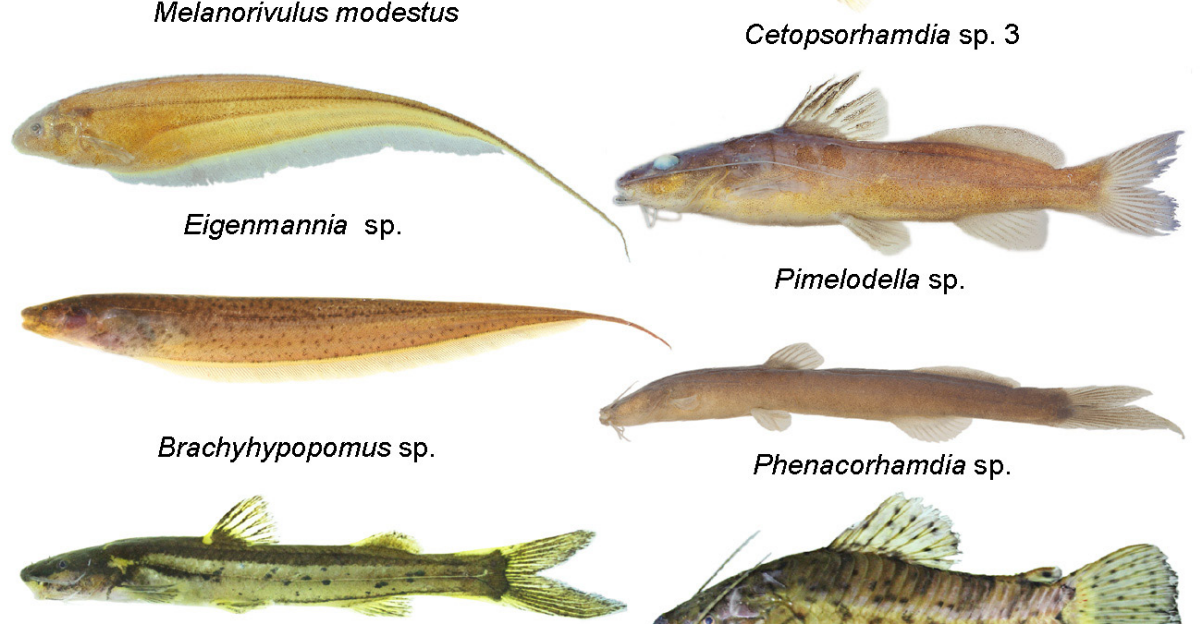

Cetopsorhamdia sp. 1

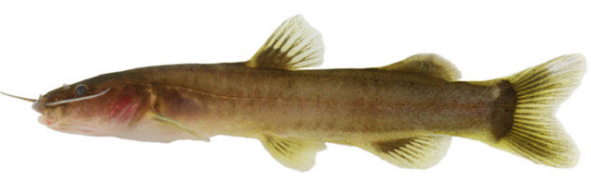

Cetopsorhamdia sp. 2
Pimelodella sp.

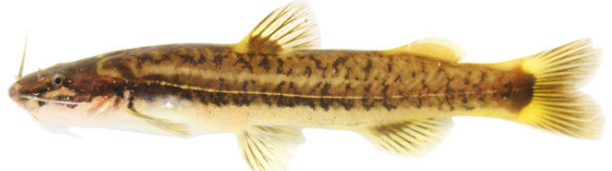

Cetopsorhamdia sp. 3

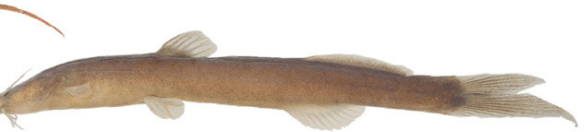

Phenacorhamdia sp.

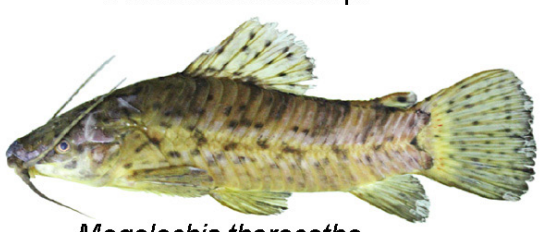

Megalechis thoracatha

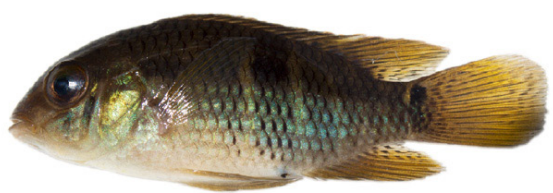

Aequidens cf. rondoni

Figure 4. Cyprinodontiformes, Gymnotiformes Siluriformes, and Labriformes registered from the upper rio Juruena, rio Tapajós basin, Mato Grosso, Brazil. 
(2 species, 11 specimens), Gymnotiformes (1 species, 9 specimens), Labriformes ( 1 species, 16 specimens) and Cyprinodontiformes ( 1 species, 3 specimens). The most representative family in number of species and specimens was Characidae, with four recorded species, including the two most abundant species registered in the igarapé 12 de Outubro basin:

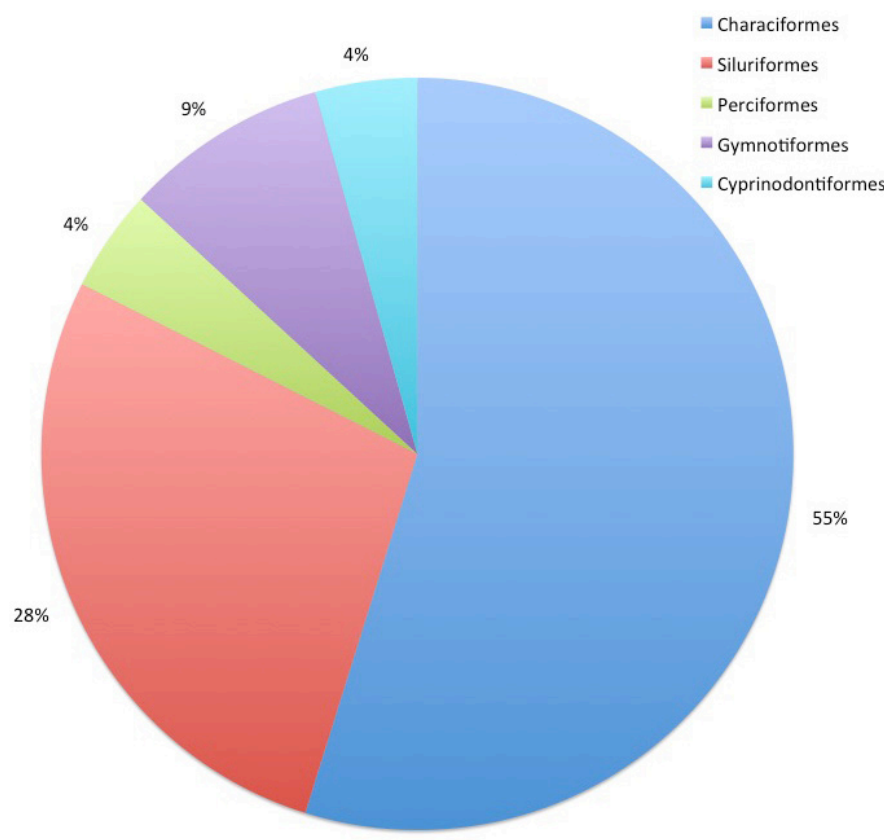

Figure 5. Relative diversity of species among the five orders registered from the upper rio Tapajós basin.

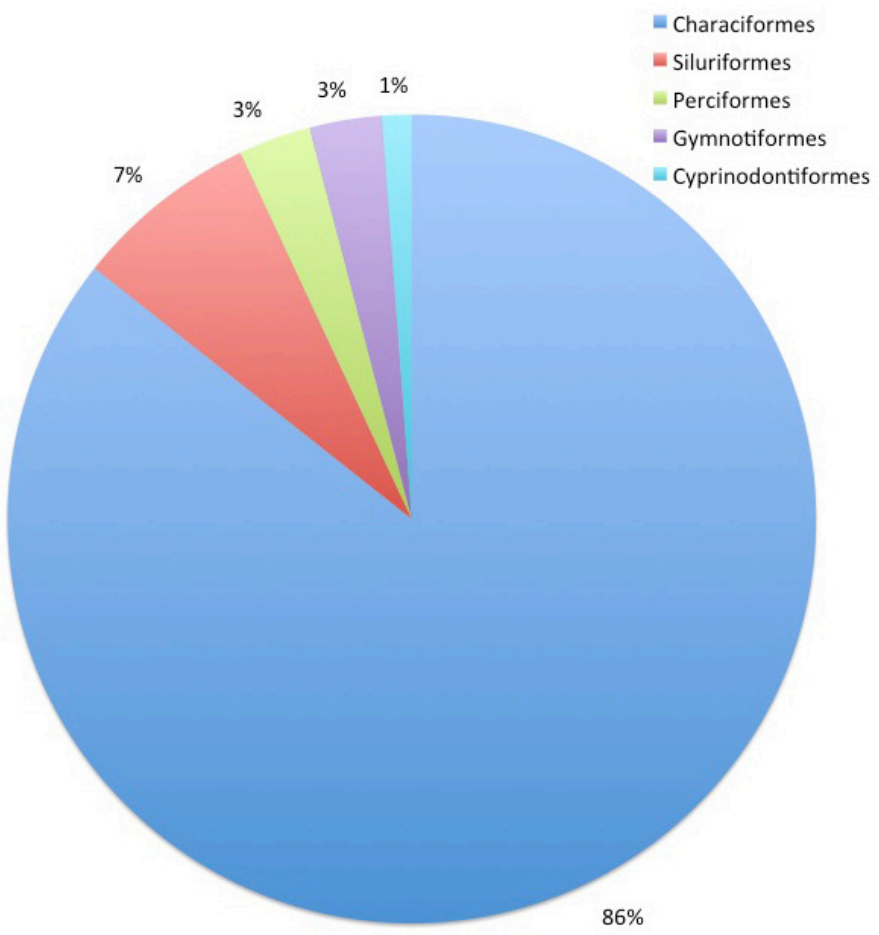

Figure 6. Relative abundance of number of species and number of individuals registered in each sample station in the four stations sampled, upper rio Tapajós basin.
Hyphessobrycon melanostichos and H. notidanos, with 421 and 99 captured specimens respectively.

Nine captured species (43\%) were identified as "sp.", including two Characiformes, five (all) Heptapteridae and two (all) Gymnotiformes. Three of the Heptapteridae species, and the two Gymnotiformes species were herein recognized as undescribed species, however more undescribed species herein registered could be recognized in the future with additional research Moreover, Cetopsorhamdia sp.1, Cetopsorhamdia sp.2 (Heptapteridae), Brachyhypopomus sp.n. and Eigenmannia sp.n. (Gymnotiformes) are currently under taxonomic revisions and preliminary examination indicates that they could represent new species endemic for the rio Juruena (Bockmann pers. communication for Heptapteridae and Ohara. personal observation for Gymnotiformes). Other four species (19\%) were tentatively identified indicating that more taxonomic studies on the neotropical ichthyofauna are needed.

No threatened species were found, however four endemic species to the upper rio Tapajós basin were recorded. Melanorivulus modestus, and H. nambiquara are only known from the igarapé Mutum and Hyphessobrycon notidanos is only known from the igarapé 12 de Outubro. Even though Hemigrammus skolioplatus is known from both the igarapé Mutum and the igarapé 12 de Outubro, it occurs only in a small restricted area.

\section{Discussion}

Available literature records about the ichthyofauna of the rio Tapajós basin are primarily concerned with the description of new species (Bertaco \& Malabarba 2007, Bertaco \& Carvalho 2005a, b, Bertaco \& Garutti 2007, Birindelli et al. 2008, Birindelli \& Britski 2013, Birindelli et al. 2013, Britski \& Garavello 1980, 1993, 2005, 2007, Britski \& Lima 2008, Caires \& Figueiredo 2011, Caires 2013, Calegari et al. 2013, Carvalho \& Bertaco 2006, Castro 1993, Carvalho \& Datovo 2012, Campos-da-Paz 2002, Costa 1991, 1994, 2007, Dagosta \& Pastana 2014, Dagosta \& Netto-Ferreira 2015, Dagosta et al. 2016, Eigenmann 1908, 1917, de Oliveira et al. 2010, 2016, Dutra et al. 2012, Espíndola et al. 2014, Fink 1979, Feitosa et al. 2011, Ferreira \& Netto-Ferreira 2010, Fichberg et al. 2014, Fink 1979, Fisch-Muller et al. 2005a, b, Géry 1980, Hollanda-Carvalho \& Weber 2005, Isbrücker \& Nijessen 1989, Kullander 1988, Kullander 1990, Kullander \& Ferreira 2006, Langeani 1999, Lima et al. 2007, 2009, 2014, Lima \& Flausino 2016, Loeb 2012, Lucena 2003, Lujan et al. 2010, Lundberg \& Mago-Leccia 1986, Marinho \& Langeani 2010, Marinho \& Lima 2009, Marinho et al. 2016a, b, Mendonça et al. 2016, Menezes 1987, 2006, Miranda-Ribeiro 1918, 1920, 1937, Moreira et al. 2002, Netto-Ferreira et al. 2009, Netto-Ferreira \& Marinho 2013, Netto-Ferreira, Marinho \& Vari 2011, Netto-Ferreira et al. 2014, Nijssen \& Isbrücker 1976, 1987, Nijssen 1972, Oyakawa \& Mattox 2009, Oliveira \& Marinho 2016, Pastana \& Dagosta 2014, Pereira \& Castro 2014, Roberts 2013, Römer et al. 2010, Sabaj-Pérez \& Birindelli 2013, Sarmento-Soares et al. 2013, Silva et al. 2014, Silva et al. 2015, Sousa et al. 2010, Scharcansky \& Lucena 2007, Teixeira et al. 2014, 2016, Toledo-Piza et al. 1999, Varella et al. 2012, Vari 1989, Vari \& Calegari 2014, Vari 1992, Vari et al. 2005, 2012, Vari \& Goulding 1985, Weitzman et al. 2005, Weitzman 1978, Zanata 1997, Zanata et al. 2010, Zawadzki et al. 2015). However, a recent unpublished survey of the fishes from the lower and middle rio Teles Pires basin, recorded 355 species (Ohara \& Lima pers. obs.). According to the authors, based on the available literature and the analyses of fish specimens deposited in museums at least 620 species may occur in the rio Tapajós basin, $12 \%$ of which are probably endemic.

A comparison of the species herein recorded and the fish assemblage from the lower portion of the rio Tapajós basin was performed based on the available literature (Ferreira et al. 1998, Camargo et al. 2005, SilvaOliveira et al. 2016) and no common species between two portions was observed. The headwater streams seem to harbor a unique species assemblage 
due to observed differences in abiotic factors such as temperature, light, hydrologic regime, water chemistry, substrate type, food resources and species pool influenced by small-scale differences in local conditions (Meyer et al. 2007).

A high number of species and specimens were captured in the igarapé Mutum, with the highest values obtained for the survey undertaken in Station 1, and the lowest values in Station 2. On the other hand, a low number of species and specimens were captured in the igarapé 12 de Outubro. Differences on environmental heterogeneity and presence of riparian vegetation were herein registered, however, the number of species and specimens captured should not be compared within this survey due to the non-standardization of the sampling effort in the field trips.

Four endemic species to the upper rio Tapajós basin were herein registered, including Hasemania nambiquara, Hemigrammus skolioplatus Bertaco \& Carvalho, 2005, Hyphessobrycon notidanos and Melanorivulus modestus. Although, Hyphessobrycon hexastichos and H. melanostichos have distribution range apparently restricted to the Chapada dos Parecis, they also were collected in the upper rio Guapore ( $\left.13^{\circ} 14^{\prime} 43^{\prime \prime} \mathrm{S} 59^{\circ} 54^{\prime} 26^{\prime \prime} \mathrm{W}\right)$, rio Madeira basin and in the igarapé Piracolina (12 $\left.49^{\prime} 58^{\prime \prime} \mathrm{S} 60^{\circ} 06^{\prime} 34^{\prime \prime} \mathrm{W}\right)$, upper rio Machado, rio Madeira basin (cf. Ohara \& Lima 2015, Ohara \& Marinho 2016, Ohara et al. 2016), respectively. So Hyphessobrycon hexastichos and $H$. melanostichos are not herein considered as endemic species for the upper rio Tapajós. According to Ohara \& Lima (2015) a large number of fish species from the upper rio Juruena are found exclusively in the headwater rivers of the Chapada dos Parecis, which suggests that the area has apparently an endemic ichthyofauna that differs from rest of the rio Tapajós basin, including the rio Teles Pires.

Additionally, as stated by Meyer et al. (2007) fish fauna from headwater streams can make a significant contribution to regional fish diversity. The presence of a high number of endemic fish and at least five new species in a small portion of the upper rio Juruena indicates it as a hotspot area for fish diversity, and as such as having potential priority for conservation measures (Carvalho \& Bertaco 2006, Britski \& Lima 2008, Ohara \& Lima 2015).

\section{Acknowledgements}

This work is part of the project "Monitoramento e Conservação da Ictiofauna do rio Madeira", a partnership involving the Universidade Federal de Rondônia, Instituto de Estudos e Pesquisas do Agronegócio e Organizações Sustentáveis and Santo Antônio Energia (2009-2012). We thank the Fundação de Amparo à Pesquisa do Estado de São Paulo for financial support of thematic project "South America Characiformes Inventory" (grant \# 11/50282-7), Naércio Menezes and Murilo Pastana (MZUSP) for their valuable suggestions on the manuscript. The authors are deeply grateful Bruno S. Barros (Naturae), Diogo Hungria (GIA), Fabiola Vieira, Ariana Cella-Ribeiro (UNIR), Fernando Dagosta (MZUSP) and Cintia Lucas (FSL) for help and assistance during the field work, and to Osvaldo Oyakawa, Michel Gianeti (MZUSP), Mariluce Messias, Ângela Araujo and Maria Cunha (UFRO) for curatorial assistance and loan of specimens. Manoela Marinho (MZUSP) for Fig. 1 and Bruno Barros for images (Pimelodella sp., Moenkhausia sp., and Phenacorhamdia sp.). Thanks are also due to the editor and both anonymous reviewers. WMO is supported by FAPESP (Process 2013/22473-8) and ML was funded by FAPESP (Process 2011/06830-0).

\section{Author Contributions}

Substantial contribution in the concept and design of the study: WMO

Contribution to data collection: WMO

Contribution to data analysis and interpretation: ML

Contribution to manuscript preparation: WMO; $\mathrm{ML}$

Contribution to critical revision, adding intelectual content: WMO; ML

\section{References}

ALBERT, J., PETRY, P. \& REIS, R.E. 2011. Major biogeographic and phylogenetic patterns. In Historical Biogeography of Neotropical Freshwater Fishes (J.S. Albert \& R.E. Reis, org.). University of California Press, Berkeley, v.1, p.21-57.

BERTACO, V.A. \& MALABARBA, L.R. 2007. A new species of Hasemania from the Upper Rio Tapajós drainage, Brazil (Teleostei: Characiformes: Characidae). Copeia 2007(2):350-354.

BERTACO, V.A. \& CARVALHO, T.P. 2005a. A new characid fish, Hyphessobrycon hexastichos (Characiformes: Characidae) from Chapada dos Parecis, Mato Grosso, Brazil. Neotropical Ichthyology 3(3):439-443.

BERTACO, V.A. \& CARVALHO, T.P. 2005b. New characid fish, Hemigrammus skolioplatus (Characiformes: Characidae) from upper Rio Tapajós drainage, central Brazil. Comunicações do Museu de Ciências e Tecnologia da PUCRS, Série Zoologia 18(2):141-150.

BERTACO, V.A. \& GARUTTI, V. 2007. New Astyanax from the upper rio Tapajós drainage, central Brazil (Characiformes: Characidae). Neotropical Ichthyology $5(1): 25-30$

BIRINDELLI, J.L.O. \& BRITSKI, H.A. 2013. Two new species of Leporinus (Characiformes: Anostomidae) from the Brazilian Amazon, and redescription of Leporinus striata Kner 1858. Journal of Fish Biology 83(5):1128-1160.

BIRINDELLI, J.L.O., BRITSKI, H.A. \& LIMA, F.C.T. 2013. New species of Leporinus from the rio Tapajós basin, Brazil, and redescription of $L$. moralesi (Characiformes: Anostomidae). Copeia (2):238-247.

BIRINDELLI, J.L.O., L.M. SOUSA \& SABAJ-PEREZ, M.H. 2008. New species of thorny catfish, genus Leptodoras Boulenger (Siluriformes: Doradidae), from Tapajós and Xingu basins, Brazil. Neotropical Ichthyology 6(3):465-480.

BRITSKI, H.A.\& GARAVELLO, J.C. 1980. Sobre uma nova espécie de Leporinus da bacia amazônica (Pisces, Anostomidae) com considerações sobre L. striatus Kner, 1859 e espécies afins. Papéis Avulsos de Zoologia 33(15):253-262.

BRITSKI, H.A. \& GARAVELLO, J.C. 1993. Descrição de duas espécies novas de Leporinus da bacia do Tapajós (Pisces, Characiformes). Comunicações do Museu de Ciências de PUCRS, Série Zoologia 6:29-40.

BRITSKI, H.A. \& GARAVELLO, J.C. 2005. Uma nova espécie de Leporinus Agassiz,1829, da bacia Amazónica (Ostariophysi: Characiformes: Anostomidae). Comunicações do Museu de Ciências e Tecnologia da PUCRS, Série Zoologia 18(2):75-83.

BRITSKI, H.A. \& GARAVELLO, J.C. 2007. Description of two new sympatric species of the genus Hisonotus Eigenmann and Eigenmann, 1889, from upper Rio Tapajós, Mato Grosso state, Brazil (Pisces: Ostariophysi: Loricariidae). Brazilian Journal of Biology 67(3):413-420.

BRITSKI, H.A. \& LIMA, F.C.T. 2008. A new species of Hemigrammus from the upper Rio Tapajós basin in Brazil (Teleostei: Characiformes: Characidae). Copeia (3):565-559.

CAIRES, R.A. \& FIGUEIREDO, J.L. 2011. Review of the genus Microphilypnus Myers, 1927 (Teleostei: Gobioidei: Eleotridae) from the lower Amazon basin, with description of one new species. Zootaxa 3036:39-57.

CAIRES, R.A. 2013. Microphilypnus tapajosensis, a new species of eleotridid from the Tapajós basin, Brazil (Gobioidei: Eleotrididae [sic]). Ichthyological Exploration of Freshwaters 23(2):155-160.

CAIRES, R.A. \& FIGUEIREDO, J.L. 2011. The northernmost record of Bassanago albescens and comments on the occurrence of Rhynchoconger guppyi (Teleostei: Anguilliformes: Congridae) along the Brazilian coast. Journal of Fish Biology 78:366-372.

CALEGARI, B.B., REIS, R.E. \& VARI, R.P. 2013. Miniature catfishes of the genus Gelanoglanis (Siluriformes: Auchenipteridae): monophyly and the description of a new species from the upper rio Tapajós basin, Brazil. Neotropical Ichthyology 12(4):699-706.

CAMARGO, M., GIARIZZO, T. \& CARVALHO Jr., J. 2005. Levantamento ecológico rápido da fauna ictica de tributários do Médio-baixo Tapajós e Curuá. Boletim do Museu Paraense Emílio Goeldi 1(2):213-231.

CAMPOS-DA-PAZ, R. 2002. Gymnotus diamantinensis, a new species of electric knifefish from upper rio Arinos basin, Brazil (Ostariophysi: Gymnotidae). Ichthyological Exploration of Freshwaters 13(2):185-192. 
CARVALHO, M. \& DATOVO, A. 2012. A new species of cascudinho of the genus Hisonotus (Siluriformes: Loricariidae: Hypoptopomatinae) from the upper Rio Tapajós basin, Brazil. Copeia (2):266-275.

CARVALHO, T.P. \& BERTACO, V.A. 2006. Two new species of Hyphessobrycon (Teleostei: Characidae) from upper rio Tapajós basin on Chapada dos Parecis, central Brazil. Neotropical Ichthyology 4(3):301-308.

CASTRO, R.M.C. 1993. Prochilodus britskii, a new species of prochilodontid fish (Ostariophysi: Characiformes), from the rio Apiacá, rio Tapajós system, Mato Grosso, Brazil. Proceedings of the Biological Society of Washington 106(1):57-62

COSTA, W.J.E.M. 1991. Redescrição do gênero Rivulus (Cyprinodontiformes, Rivulidae), com notas sobre $R$. stellifer e $R$. compactus e a descrição de duas novas espécies do Brazil central. Revista Brasileira de Biologia 51(2):327-333.

COSTA, W.J.E.M. 1994. Description of two new species of the genus Moenkhausia (Characiformes: Characidae) from the central Brazil. Zoologischer Anzeiger 232(1-2):21-29.

COSTA, W.J.E.M. 2007. Redescription of Rivulus luelingi and R. haraldsiolii (Teleostei: Cyprinodontiformes: Rivulidae), two valid killifish species from the Atlantic forest of the coastal plains of southern Brazil. Ichthyological Exploration of Freshwaters 18(2):175-182.

COSTA, W.J.E.M. 2008. Rivulus kayabi, a new killifish from the Tapajós River basin, southern Brazilian Amazon (Cyprinodontiformes: Rivulidae). Ichthyological Exploration of Freshwaters18(4):345-350

DAGOSTA, F.C.P. \& NETTO-FERREIRA, A.L 2015. New species of Bryconamericus Eigenmann (Characiformes: Characidae) from the rio Teles Pires, rio Tapajós basin, central Brazil. Zootaxa 3911(3):433-442.

DAGOSTA, F.C.P. \& PASTANA, M.N.L. 2014. New species of Creagrutus Günther (Characiformes: Characidae) from rio Tapajós basin, Brazil, with comments on its phylogenetic position. Zootaxa 3765(6):571-582.

DAGOSTA, F.C.P., MARINHO, M.M.F., CAMELIER, P. \& LIMA, F.C.T. 2016. A new species of Hyphessobrycon (Characiformes: Characidae) from the upper Rio Juruena basin, Central Brazil, with a redescription of $H$. cyanotaenia. Copeia 104(1):250-259.

DE OLIVEIRA, R.R., ZUANON, J., RAPP PY-DANIEL, L. \& ROCHA, M.S 2010. Peckoltia compta, a new species of catfish from the Brazilian Amazon, rio Tapajós basin (Siluriformes: Loricariidae). Zootaxa 2534:48-56

DE OLIVEIRA, R.R., RAPP PY-DANIEL, L., ZAWADZKI, C.H. \& ZUANON, J. 2016. Two new Amazonian species of Ancistrus with vestigial adipose fin, with an appraisal on adipose fin loss in neotropical armoured catfishes (Teleostei Loricariidae). Ichthyological Exploration of Freshwaters 27(1):67-80.

DUTRA, G.M., WOSIACKI, W.B. \& PINNA, M.C.C. 2012. Trichomycterus anhanga, a new species of miniature catfish related to T. hasemani and T. johnsoni (Siluriformes: Trichomycteridae) from the Amazon basin, Brazil. Neotropical Ichthyology 10(2):225-231.

EIGENMANN, C.H. 1917. The American Characidae [Part 1]. Memoirs of the Museum of Comparative Zoology 43(1):1-102.

EIGENMANN, C.H. 1908. Preliminary descriptions of new genera and species of tetragonopterid characins. (Zoölogical Results of the Thayer Brazilian expedition.). Bulletin of the Museum of Comparative Zoology 52 (6):91-106.

ESPÍNDOLA, V.C., SPENCER, M.R.S., ROCHA, L.R.\& BRITTO, M.R. 2014 A new species of Corydoras Lacépède (Siluriformes: Callichthyidae) from the Rio Tapajós basin and its phylogenetic implications. Papéis Avulsos de Zoologia, São Paulo 54(3):25-32.

FEITOSA, F.S., SANTOS, G.M. \& BIRINDELLI, J.L.O. 2011. Leporinus britskii: a new anostomid from the Tapajós and Jari drainages, Brazil (Characiformes: Anostomidae). Zootaxa 3120:55-62.

FERREIRA, E.J.G., ZUANON, J.A.S. \& SANTOS, G.M. 1998. Peixes comerciais do médio Amazonas: Região de Santarém, Pará. Divisão de Divulgação TécnicoCientífica IBAMA, Brasília.

FERREIRA, K.M. \& NETTO-FERREIRA, A.L. 2010. Knodus dorsomaculatus (Characiformes: Characidae), a new species from Teles Pires River, Tapajós River basin, Brazil. Journal of Fish Biology 77(3):468-478.

FICHBERG, I., OYAKAWA, O.T. \& PINNA, M.C.C. 2014. The end of an almost 70-year wait: a new species of Spatuloricaria (Siluriformes: Loricariidae) from the Rio Xingu and Rio Tapajós basins. Copeia (2):317-324.
FINK, W.L. 1979. A new species of Moenkhausia from the Mato Grosso region of Brazil (Pisces: Characidae). Breviora 450:1-12.

FISCH-MULLER, S., CARDOSO, A.R., SILVA, J.F.P. \& BERTACO, V.A. 2005a Two new Amazonian species of armored catfishes (Siluriformes: Loricariidae): Ancistrus verecundus and Ancistrus parecis. Neotropical Ichthyology 3(4):525-532.

FISCH-MULLER, S., CARDOSO, A.R., SILVA, J.F.P. \& BERTACO, V.A. 2005b Three new species of Ancistrus Kner (Teleostei: Siluriformes: Loricariidae) from the upper Tapajós and Tocantins rivers. Revue Suisse de Zoologie 112(2):559-572.

GÉRY, J. 1980. Un nouveau Poisson characoïde occupant la niche des mangeurs d'écailles dans le haut rio Tapajoz, Brésil: Bryconexodon juruenae n. g. sp. Revue française d'Aquariologie Herpétologie 7(1):1-8.

HOLLANDA CARVALHO, P. \& WEBER, C. 2005. Five new species of the Hypostomus cochliodon group (Siluriformes: Loricariidae) from the middle and lower Amazon System. Revue Suisse de Zoologie 111(4):953-978.

ISBRÜCKER, I.J.H. \& NIJSSEN, H. 1989. Diagnose dreier neuer Harnischwelsgattungen mit fünf neuen Arten aus Brasilien (Pisces, Siluriformes, Loricariidae). DATZ 42(9):541-547.

KULLANDER, S.O. 1988. Teleocichla, a new genus of South American rheophilic cichlid fishes with six new species (Teleostei: Cichlidae). Copeia (1):196-230.

KULLANDER, S.O.\& FERREIRA, E.J.G. 2006. A review of the South American cichlid genus Cichla, with descriptions of nine new species (Teleostei: Cichlidae). Ichthyological Exploration of Freshwaters 17(4):289-398.

LANGEANI, F. 1999. Argonectes robertsi sp. n., um novo Bivibranchiinae (Pisces, Characiformes, Hemiodontidae) dos rios Tapajós, Xingu, Tocantins e Capim, drenagem do rio Amazonas. Naturalia 23:171-183.

LIMA, F.C.T. \& FLAUSINO, N.Jr. 2016. Hyphessobrycon vanzolinii, a new species from rio Tapajós, Amazon basin, Brazil (Characiformes: Characidae). Aqua, International Journal of Ichthyology 22(2):89-95.

LIMA, F.C.T., BRITSKI, H.A. \& MACHADO, F.A. 2007. A new Moenkhausia (Characiformes: Characidae) from central Brazil, with comments on the area relationship between the upper rio Tapajós and upper rio Paraguai systems. Aqua, International Journal of Ichthyology 13(2):45-54

LIMA, F.C.T., WOSIACKI, W.B. \& RAMOS, C.S. 2009. Hemigrammus arua, a new species of characid (Characiformes: Characidae) from the lower Amazon, Brazil. Neotropical Ichthyology 7(2):153-160.

LIMA, F.C.T., COUTINHO, D.P. \& WOSIACKI, W.B. 2014. A new Hyphessobrycon (Ostariophysi: Characiformes: Characidae) from the middle Amazon basin, Brazil. Zootaxa (2):167-179.

LOEB, M.V. 2012. A new species of Anchoviella Fowler, 1911 (Clupeiformes: Engraulidae) from the Amazon basin, Brazil. Neotropical Ichthyology 10(1):13-18

LUCENA, C.A.S. 2003. New characid fish, Hyphessobrycon scutulatus, from the rio Teles Pires drainage, upper rio Tapajós system (Ostariophysi: Characiformes: Characidae). Neotropical Ichthyology 1(2):93-96.

LUJAN, N.K., HIDALGO, M. \& STEWART, D.J. 2010. Revision of Panaque (Panaque), with descriptions of three new species from the Amazon basin (Siluriformes, Loricariidae). Copeia 4: 676-704.

LUNDBERG J.G. \& MAGO-LECCIA, F. 1986. A review of Rhabdolichops (Gymnotiformes, Sternopygidae), a genus of South American freshwater fishes, with descriptions of four new species. Proceedings of the Academy of Natural Sciences of Philadelphia 138:53-85.

MARINHO, M.M.F. \& LIMA, F.C.T. 2009. Astyanax ajuricaba: a new species from the Amazon basin in Brazil (Characiformes: Characidae). Neotropical Ichthyology 7 (2):169-174.

MARINHO, M.M.F. \& LANGEANI, F. 2010. Moenkhausia celibela: a new species from the Amazon basin, Brazil (Characiformes: Characidae). Journal of Fish Biology 77(4):879-889.

MARINHO, M.M.F., DAGOSTA, F.C.P., CAMELIER, P. \& LIMA, F.C.T. 2016. Description of a new species of Moenkhausia (Characiformes, Characidae) from the Upper Rio Tapajós Basin, Brazil. Copeia 104(1):243-249.

MARINHO, M.M.F., DAGOSTA, F.C.P., CAMELIER, P. \& OYAKAWA, O.T. 2016. A name for the 'blueberry tetra', an aquarium trade popular species of Hyphessobrycon Durbin (Characiformes, Characidae), with comments on fish species descriptions lacking accurate type locality. Journal of Fish Biology, 1-12. 
MENDONÇA, M.B., PEIXOTO, L.A.W., DUTRA, G.M. \& NETTO-FERREIRA, A.L. 2016. A new miniature of Xenurobryconini (Characiformes: Characidae) from the rio Tapajós basin, Brazil. Neotropical Ichthyology 14(1):45-52.

MENEZES, N.A. 1987. Three new species of the characid genus Cynopotamus Valenciennes, 1849, with remarks on the remaining species (Pisces, Characiformes). Beaufortia 37(1):1-9.

MENEZES, N.A. 2006. Description of five new species of Acestrocephalus Eigenmann and redescription of $A$. sardina and A. boehlkei (Characiformes: Characidae). Neotropical Ichthyology 4(4):385-400.

MEYER, J.L., STRAYER, D.L., WALLACE, J.B., EGGERT, S.L., HELFMAN, G.S. \& LEONARD, N.E. 2007. The contribution of headwater streams to biodiversity in river networks. Journal of the American Water Resources Association 43(1):86-103.

MIRANDA RIBEIRO, A. 1918. Historia Natural. Zoologia. Cichlidae. In: Commissão de Linhas Telegraphicas Estrategicas de Matto-Grosso ao Amazonas. Publ. 46:1-18.

MIRANDA RIBEIRO, A. 1920. Peixes (excl. Characinidae). In: Commissão de Linhas Telegraphicas Estrategicas de Matto-Grosso ao Amazonas. Historia Natural, Zoologia, Anexo 5 58:1-15.

MIRANDA RIBEIRO, A. 1937. Considerações preliminares sobre a zoogeografia Brasilica. IV. O Campo. Rio de Janeiro. 8:58-59.

MOREIRA, C.R., LANDIM, M.I. \& COSTA, W.J.E.M. 2002. Hyphyessobrycon heliacus: a new characid fish (Ostariophysi: Characiformes) from the upper Rio Tapajós basin, central Brazil. Copeia (2):428-432.

NETTO-FERREIRA, A.L. \& VARI, R.P. 2011. New species of Steindachnerina (Characiformes: Curimatidae) from the Rio Tapajós, Brazil, and review of the genus in the Rio Tapajós and Rio Xingu basins. Copeia (4):523-529.

NETTO-FERREIRA, A.L. \& MARINHO, M.M.F. 2013. New species of Pyrrhulina (Osteichthys: Characiformes: Lebiasinidae) from the Brazilian Shield, with comments on a putative monophyletic group of species in the genus. Zootaxa (3):369-376.

NETTO-FERREIRA, A.L., ZANATA, A.M., BIRINDELLI, J.L.O. \& SOUSA, L.M. 2009. Two new species of Jupiaba (Characiformes: Characidae) from the rio Tapajós and rio Madeira drainages, Brazil, with an identification key to the species of the genus. Zootaxa 2262:53-68.

NETTO-FERREIRA, A.L., BIRINDELLI, J.L.O., SOUSA, L.M. \& MENEZES, N.A. 2014. A new species of Rhinopetitia Géry 1964 (Ostariophysi: Characiformes: Characidae) from the Rio Teles Pires, Rio Tapajós basin, Brazil. Journal of Fish Biology 84(5):1539-1550.

NIJSSEN, H. \& ISBRÜCKER, I.J.H. 1976. Corydoras ornatus, a new species of callichthyid catfish from the Rio Tapajós drainage, Brazil (Pisces, Siluriformes, Callichthyidae). Bulletin Zoölogisch Museum, Universiteit van Amsterdam 5(15):125-129.

NIJSSEN, H. \& ISBRÜCKER, I.J.H. 1987. Spectracanthicus murinus, nouveaux genre et espèce de poisson-chat cuirassé du Rio Tapajós, Est. Pará, Brésil, avec des remarques sur d'autres genres de Loricariidés (Pisces, Siluriformes, Loricariidae). Revue française d'Aquariologie Herpétologie 13(4):93-98.

NIJSSEN, H. 1972. Records of the catfish genus Corydoras from Brazil and French Guiana with descriptions of eight new species (Pisces, Siluriformes, Callichthyidae). Netherlands Journal of Zoology 21(4):412-433,

OHARA, W.M. \& LIMA, F.C.T. 2015. Hyphessobrycon lucenorum (Characiformes: Characidae), a new species from the rio Madeira basin, Rondônia State, Brazil. Zootaxa 3972(4):562-572.

OHARA, W.M. \& MARINHO, M.M.F. 2016. A new species of Moenkhausia Eigenmann (Characiformes: Characidae) from the upper rio Machado at Chapada dos Parecis, rio Madeira basin, Brazil. Neotropical Ichthyology 14(1):e150041.

OHARA, W.M., TENCATT, L.F.C. \& BRITTO, M.R. Wrapped in flames: Corydoras hephaestus, a new remarkably colored species from the Rio Madeira basin (Teleostei: Callichthyidae). Zootaxa 4170(3): 539-52.

OLIVEIRA, G.D. \& MARINHO, M.M.F. 2016. A new species of Moenkhausia Eigenmann, 1903 (Characiformes, Characidae) from the rio Amazonas basin, Brazil. Zootaxa 4093 (4):566-574.

OYAKAWA, O.T. \& MATTOX, G.M.T. 2009. Revision of the Neotropical trahiras of the Hoplias lacerdae species-group (Ostariophysi: Characiformes: Erythrinidae) with descriptions of two new species. Neotropical Ichthyology 7(2):117-140.
PASTANA, M.N.L. \& DAGOSTA, F.C.P. 2014. Moenkhausia rubra, a new species from rio Juruena, upper rio Tapajós basin, Brazil (Characiformes: Characidae). Neotropical Ichthyology12(2):389-396.

PEREIRA, T.N.A. \& CASTRO, R.M.C. 2014. A new species of Utiaritichthys Miranda Ribeiro (Characiformes: Serrasalmidae) from the Serra dos Parecis, Tapajós drainage. Neotropical Ichthyology12(2):397-402.

QUEIROZ, L.J., TORRENTE-VILARA, G., OHARA, W.M., PIRES, T., ZUANON, J.A. \& DORIA, C.R. 2013. Peixes do rio Madeira. 1 ed. v.3. Dialeto, São Paulo.

REIS, R.E., KULLANDER, S.O. \& FERRARIS, C.J. 2003. Check list of the freshwater fishes of South and Central America. Edipucrs, Porto Alegre.

REIS, R.E. 2013. Conserving the freshwater fishes of South America. International Zoo Yearbook 47:65-70.

REIS, R.E., LE BAIL, P.-Y. \& MOL, J.H.A. 2005. New arrangement in the synonymy of Megalechis Reis, 1997 (Siluriformes: Callichthyidae). Copeia (3):678-682.

REIS, R.E., ALBERT, J.S., DIDARIO, F., MINCARONE, M.M., PETRY, P. \& ROCHA, L.A. 2016. Fish biodiversity and conservation in South America. Journal of Fish Biology, in press.

ROBERTS, T.R. 2013. Leptophilypnion, a new genus with two new species of tiny central Amazonian gobioid fishes (Teleostei, Eleotridae). aqua, International Journal of Ichthyology 19(2):85-98

RÖMER, U., HAHN, I.J. \& VERGARA, P.M. 2010. Description of Dicrossus foirni sp. n. and Dicrossus warzeli sp. n. (Teleostei: Labriformes: Cichlidae), two new cichlid species from the Rio Negro and the Rio Tapajós, Amazon drainage, Brazil. Vertebrate Zoology 60(2):123-138.

SABAJ-PÉREZ, M.H. \& BIRINDELLI, J.L.O. 2013. Hassar shewellkeimi, a new species of thorny catfish (Siluriformes: Doradidae) from the upper Tapajós basin, Brazil. Proceedings of the Academy of Natural Sciences of Philadelphia 162:133-156

SARMENTO-SOARES, L.M., CABECEIRA, F.G., CARVALHO, L.N., ZUANON, J. \& AKAMA, A. 2013. Centromochlus meridionalis, a new catfish species from the southern Amazonian limits, Mato Grosso State, Brazil (Siluriformes: Auchenipteridae). Neotropical Ichthyology 11(4):797-808.

SCHAEFER, S.A. 1998. Conflict and resolution: impact of new taxa on phylogenetic studies of the Neotropical cascudinhos (Siluroidei: Loricariidae). In Phylogeny and classification of Neotropical fishes: 375-400. Malabarba, L. R., Reis, R. E., Vari, R. P., Lucena, Z. M. S. \& Lucena, C. A. S. (Eds). Porto Alegre: Edipucrs.

SCHARCANSKY, A. \& LUCENA, C.A.S. 2007. Caenotropus schizodon, a new chilodontid fish from the Rio Tapajós drainage, Brazil (Ostariophysi: Characiformes: Chilodontidae). Zootaxa 1557:59-66.

SILVA-OLIVEIRA, C., CANTO, A.L.C. \& RIBEIRO, F.R.V. 2015. Bryconops munduruku (Characiformes: Characidae), a new species of fish from the lower Tapajós River basin, Brazil. Zootaxa 3994(1):133-141.

SILVA, G.S.C., ROXO, F.F., BRITZKE, R. \& OLIVEIRA, C. 2014. New species of the Pseudancistrus barbatus group (Siluriformes, Loricariidae) with comments on its biogeography and dispersal routes. ZooKeys 406:1-23.

SILVA, G.S.C., ROXO, F.F. \& OLIVEIRA, C. 2015. Two new species of Pseudancistrus (Siluriformes, Loricariidae) from the Amazon basin, northern Brazil. ZooKeys 482:21-34.

SOUSA, L.M., NETTO-FERREIRA, A.L. \& BIRINDELLI, J.L.O. 2010. Two new species of Moenkhausia Eigenmann (Characiformes: Characidae) from Serra do Cachimbo, Pará, northern Brazil. Neotropical Ichthyology 8(2):255-264.

TEIXEIRA, T.F., LIMA, F.C.T. \& ZUANON, J. 2014. A new Hyphessobrycon Durbin from the Rio Teles Pires, Rio Tapajós Basin, Mato Grosso State, Brazil (Characiformes: Characidae). Copeia (4):612-621.

TEIXEIRA, T.F., NETTO-FERREIRA, A.L., BIRINDELLI, J.L.O. \& SOUSA, L.M. 2016. Two new species of Hyphessobrycon (Characiformes: Characidae) from the headwaters of the Tapajós and Xingu River basins, Pará, Brazil. Journal of Fish Biology 88(2):459-476.

TOLEDO-PIZA, M., MENEZES, N.A. \& SANTOS, G.M. 1999. Revision of the neotropical fish genus Hydrolycus (Ostariophysi: Cynodontinae) with the description of two new species. Ichthyological Exploration of Freshwaters 10(3):255-280.

VAN DER LAAN R., ESCHMEYER, W.N., FRICKE, R. 2014. Family-group names of recent fishes. Zootaxa 3882:1-230. 
Ohara, W.M. \& Loeb, M.V.

VARELLA, H.R., KULLANDER, S.O. \& LIMA, F.C.T. 2012. Crenicichla chicha, a new species of pike cichlid (Teleostei: Cichlidae) from the rio Papagaio, upper rio Tapajós basin, Mato Grosso, Brazil. Neotropical Ichthyology 10(2):233-244.

VARI, R.P. 1989. Systematics of the neotropical characiform genus Curimata Bosc (Pisces: Characiformes). Smithsonian Contributions to Zoology 474:1-63.

VARI, R.P. 1992. Systematics of the neotropical Characiform genus Cyphocharax Fowler (Pisces, Ostariophysi). Smithsonian Contributions to Zoology 529:1-137.

VARI, R.P. \& CALEGARI, B.B. 2014. New species of the catfish genus Tatia (Siluriformes: Auchenipteridae) from the rio Teles Pires, upper rio Tapajós basin, Brazil. Neotropical Ichthyology 12(4):667-674.

VARI, R.P. \& GOULDING, M. 1985. A new species of Bivibranchia (Pisces: Characiformes) from the Amazon River basin. Proceedings of the Biological Society of Washington 98(4):1054-1061.

VARI, R.P., FERRARIS, C.J. Jr. \& PINNA, M.C.C. 2005. The neotropical whale catfishes (Siluriformes: Cetopsidae: Cetopsinae), a revisionary study. Neotropical Ichthyology 3(2):127-238.

VARI, R.P., SANTANA, C. D. \& WOSIACKI, W.B. 2012. South American electric knifefishes of the genus Archolaemus (Ostariophysi, Gymnotiformes): undetected diversity in a clade of rheophiles. Zoological Journal of the Linnean Society 165(3):670-699.

WEITZMAN, S.H. 1978. Three new species of fishes of the genus Nannostomus from the Brazilian states of Pará and Amazonas (Teleostei: Lebiasinidae). Smithsonian Contributions to Zoology 263:1-14.
WEITZMAN, S.H., MENEZES, N.A., EVERS, H.-G. \& BURNS, J.R. 2005 Putative relationships among inseminating and externally fertilizing characids, with a description of a new genus and species of Brazilian inseminating fish bearing an anal-fin gland in males (Characiformes: Characidae). Neotropical Ichthyology 3(3):329-360.

WILEY, E.O. \& JOHNSON, G.D. 2010. A teleost classification based on monophyletic groups. In Origin and Phylogenetic Relationships of Teleosts (J.S. Nelson, H.-P. Schultze \& M.V.H. Wilson, eds.). Verlag Dr. Pfiel, Munich, p.123-182.

ZANATA, A.M. 1997. Jupiaba, um novo gênero de Tetragonopterinae com osso pélvico em forma de espinho (Characidae, Characiformes). Iheringia, Série Zoologia 83:99-136.

ZANATA, A.M., BIRINDELLI, J.L.O. \& MOREIRA, C.R. 2010. New species of Moenkhausia Eigenmann (Characiformes: Characidae) from Rio Xingu and Rio Tapajós basins, Brazil, with comments on a putative case of polymorphic Batesian mimicry. Journal of Fish Biology 75(10):2615-2628.

ZAWADZKI, C.H., OLIVEIRA, A.S., OLIVEIRA, R.R. \& RAPP PY-DANIEL, L. 2015. Hypostomus melanephelis, a new armored catfish species from the rio Tapajós basin, Brazil (Teleostei: Loricariidae). Ichthyological Exploration of Freshwaters 26(1):49-58.

Received: $28 / 06 / 2016$

Revised: 25/08/2016

Accepted: 28/09/2016 